\title{
Suffering in world religions within paradigm of modern information
}

\author{
Ekaterina Bobyreva ${ }^{1 *}$, Olga Dmitrieva ${ }^{2}$, Tatyana Gonnova ${ }^{3}$ and Anna Oganesyan ${ }^{4}$ \\ ${ }^{1}$ Volgograd State Socio-Pedagogical University, Volgograd, Russia, new_life@mail.ru \\ ${ }^{2}$ Volgograd State Socio-Pedagogical University, Volgograd, Russia, dmoa@yandex.ru \\ ${ }^{3}$ Volgograd State Socio-Pedagogical University, Volgograd, Russia, concept-t@mail.ru \\ ${ }^{4}$ Volgograd State Social Pedagogical University, oganesyananna1994@mail.ru
}

\begin{abstract}
Any type of discourse, along with its characteristic concepts, operates with its own values. The basis of religious discourse form universal values providing moral guidelines that represent a standard for people of different cultures and eras, which are associated with the ideals of justice and are timeless. Among the universal are cultural, social and moral values. The bulk of religious values form cultural ones in any modern society. Religious beliefs form inner culture of a person. Some religious values can be referred as social and include: meaningful (meaning of life, happiness), universal (life, health), values of interpersonal communication (benevolence), values of public recognition (hard work), democratic values (freedom of speech). In modern society among religious, social and moral (mercy, compassion) values can be distinguished. Religious values can be found within each subgroup of universal human values. The article interprets phenomenon of suffering in modern society, which is an integral component of any world religion and forms the category of value in Christianity. The analysis of suffering in the article was carried out along with the analysis of religious discourse - a special type of institutional communication that combines features of institutional-oriented and personal-oriented phenomenon. The article shows reasons for the occurrence and existence of suffering in any modern society, as well as approaches that exist in various religious systems (Christianity, Islam and Buddhism) to interpreting suffering, attitude to it, need and possibility to overcome it as well as linguistic means to express phenomenon of suffering in world religions.
\end{abstract}

\section{Introduction}

Understanding and interpretation of various phenomena and objects of the surrounding life is the basis of their acceptance by a person [1]. Religious discourse, within the framework of which phenomenon of suffering will be considered, distinguishes from all other existing types of institutional communication the open postulation of values [2]. According to E.A. Kozhemyakin, one of the features of religious discourse is the "presumption of sincerity of the subject" [3], whose statements can be assessed as "false" or "true", "correct" or "wrong", but they can never be "deliberately false" or "manipulative". One of the main argumentative tactics in religious discourse is appeal to authority. The authorities of the assessment are canonical figures, as well as "subjects whose public prestige increases the significance of their actions" [4]. In its turn, evaluation in religious discourse is based on moral and moral postulates that form the basis of this religious concept. The basic opposition "good::evil", which determines the key provisions of a particular religious doctrine, is expressed in specific categories of assessment "good::bad", "acceptable::unacceptable", "permissible::unacceptable".

\section{Problem Statement}

The basis of communication is information environment or information paradigm, in a modern interpretation. In the development of the information paradigm it is advisable to distinguish three stages: classical, nonclassical and post-classical (modern); these stages are related to cultural and historical codes of civilization. All existing information can be presented in the ontological, gnoseological, axiological aspects. Social structure is heterogeneous, analysis of given heterogeneity of society showed coexistence in any historical period of time of different value systems [5].

\section{Research Questions}

\footnotetext{
* Corresponding author: new_life@mail.ru
} 
Religious values present timeless phenomenon, they can be defined as "principles", "laws", "attitudes", "commandments", "canons", "spiritual axioms", etc.

Universal human values that form the basis of religious discourse: 1) provide fundamental moral guidelines and represent absolute standard for people of all cultures and eras; 2) connected with the ideals of humanism, justice and dignity of a person; 3) do not correspond to a specific historical period of society's development or a specific ethnic tradition.

\section{Purpose of the Study}

In the category of universal values: a) cultural values, b) social values, c) moral values can be distinguished. The bulk of religious values refer to cultural values. Religious beliefs and values are the main components of a person's daily life, forming his internal culture. At the same time, a number of religious values can be referred to social values, which include: meaningful values (ideas about happiness, purpose and meaning of life); universal values (life, health, personal security, family, law and order); values of interpersonal communication (honesty, disinterest, benevolence); values of social recognition (hard work, social status); democratic values (freedom of speech, conscience). Such values as life, family, honesty, unselfishness, etc., are central in a number of religious teachings. Therefore, among religious, a number of social values can be found. Moral values are certainly an integral part of religious values - mercy, compassion are significant values of Christian creed. Thus, religious values can be found inside each subgroup of universal human values.

\section{Research Methods}

The methodological framework of this research is the system approach. The purpose of the research is achieved by the application of the methods of semantic analysis, discourse-analysis, method of cultural meanings' analysis.

\section{Findings}

Human values are the focus of attention of various approaches and are considered by different researchers. The biogenetic concept of universal human values considers the latter as universal cultural phenomena common in their function (they satisfy the vital needs of man and society - survival, adaptation to the environment, etc.)[6].

Speaking about the values of religious discourse it seems appropriate to present the system of values in the form of peculiar oppositions. Almost all concepts that are interpreted as values have their absolute opposite "anti-value". "A person would never think about the value of common things if he did not constantly run into" forks". The choice requires motivation. And it is, as a rule, sought in practical expediency, convenience, ease, reliability, desirability and other private assessments" [7].

The peculiarity of religious values is their open statement. These values are based not on rational, but on emotional base. Higher religious values are values through which a person comes closer to God. Acquiring higher values an individual gets the opportunity to transcendence, to go beyond his private existence, to rise above it [8].

The expression "Christian values" came into at the beginning of the $20^{\text {th }}$ century. But the concept 'moral value' first appeared in the ethics of E. Kant [9].

Christianity proceeds from the understanding of value as an absolute good that is relevant in any respect and for any person. According to Yu.S. Garanov, religious (Christian) values are "absolute spiritual and moral sources of the person gaining connection with the transcendent, achieving the highest improvement, grace, salvation (liberation), spiritual immortality, mystical knowledge". The desire for these values characterizes the level of spirituality, morality of a person, orientation towards the highest ideal. Classifying Christian values, Yu.S. Garanov identifies: 1) religious-ontological values (God, existence, nature); 2) religious and anthropological values (man, soul, freedom of will, faith, hope, love, grace, salvation, etc.); 3) religious and ethical values (good, love for both neighbor and enemy, non-resistance to evil, forgiveness, suffering, martyrdom, holiness, virtue, etc.); 4) religious and aesthetic values (beauty as a reflection of God, beautiful as a form of good, etc.) endowed with sacred, mystical meaning the highest qualities of a person's sensual-figurative attitude to the world; 5) religious and cognitive values (Holy Bible Scripture and Tradition, practices of praying); 6) religious and symbolic values (icons, rites and rituals); 7) religious and social values (church, Christian community) [10].

In the most general form suffering is "a combination of unpleasant and painful sensations of a living creature, in which it experiences physical and emotional discomfort, pain, stress, torment; thus, in the most general meaning, suffering is physical or moral pain, torment" [11].

The primary basis of human suffering is inherent negative emotion of both animals and humans, "signaling about difficulties in implementing basic instinctive programs of behavior (experiencing unfulfilled or suppressed desire)" [12]. However, due to the rational nature of a person's consciousness, his suffering moves from the level of strong emotions to the level of feelings. Human suffering, therefore, is an extremely strong negative feeling in which a negative situation is experienced as a 'fragment of a dysfunctional world" which makes it impossible for a person to continue a comfortable life.

Suffering is an integral part of human existence that is why this phenomenon has a special place in each world religion. Any religion develops its own attitude to suffering and offers its own way to overcome it [13].

Christianity makes suffering absolute. An example of the highest suffering that ultimately led to salvation are sufferings of Jesus Christ himself and his death on the 
cross: "And whoever does not take his cross, does not follow me, is not worthy of me" [14].

Suffering in Christianity is considered not as a cause for sorrow but as a cause for joy because suffering endured in person's present life promises (and, to some extent, even guarantees) happiness in another life: "But as you participate in Christ's suffering, rejoice, and in the manifestation of his glory you will rejoice and triumph" [14].

Christianity to some extent convinces a person that his sufferings are only a "small fee" for the well-being and happiness that a person will get after death. Perhaps that is why, having true faith, it is easy for a person to endure physical and moral deprivation: "I think that the present temporary suffering is worthless compared to the glory that will be revealed in us" [14]. Current life, and at the same time current sufferings are defined as "temporary" ones, while the "Kingdom of God" awaiting for a suffering person is presented as eternal - such opposition "temporary::eternal", having some psychological effect on a persons who believes in God, helps him to endure current deprivations.

The idea of inevitability of suffering is also reflected in the language: "The Lord tolerated and commanded us to tolarate!". Many monks' orders consciously try to bring their lives closer to the life of Jesus. The very belief that suffering is welcomed by God led to the idea of asceticism; Christian ascesis (starvation, selfdestruction, asceticism, wearing verigs, etc.) is considered one of the ways to improve spiritually.

Suffering has a special pace in Christianity. According to John Domaskin, suffering - is a special state of man, followed by "pleasure or displeasure". "Fruits of sufferings", therefore, depend on the choice of a person himself. Christian history says that two "criminals" were crucified, but for one of them sufferings meant, while another one became even more cruel.

Christianity views present sufferings of man as a temporary stage which will necessarily be followed by "reward", "retribution" for all hardships suffered during earthly life: "As the sufferings of Christ multiply in us, Christ multiplies and our comfort is increased" [14]. Moreover, Christianity considers suffering itself as a reward sent to a person from above, and not without a reason the Bible uses the expression "you are given" but not "you have to" or "you are forced", but namely "given" - a person as a creature chosen by God is given a reward to suffer in the name of a future happy life: "You are given for the sake of Christ not only to believe in him but also to suffer for him" (Bible, 1973). This is the reason for the Christian concept that the more a person suffers the more Lord loves him.

From the point of view of Christianity suffering is not an absolute evil. Having, in fact, a negative vector of evaluation, suffering leads to good consequences. Suffering plays a purifying role: "Before my suffering I was misled; and now I keep your word" [14]. Speaking about sufferings in the Christian conception, it is worth pointing out that, first of all, they mean not body sufferings, but mental sufferings arising from inability to have what is necessary for a person in his life - food, home, family, etc. So, what it sometimes means is that very often it is not possible to meet person's basic physical or mental needs. However, according to the Apostle Paul: "The kingdom of God is not food and drink, but righteousness and peace and joy in the 'Holy Spirit"' [14], so the righteous, awaiting for future bliss, must and can enjoy the kingdom of God, which is within them.

Christianity almost always sees the cause of suffering in sins, in violation of morality and law by a person: "We suffer for our sins" [14]. In its turn, suffering has a beneficial effect on a person; Christianity teaches that suffering almost always has a certain cause and convinces that in the life there is not moral chaos but a slender order based on the truth. And it is through suffering that a man is improved. Therefore, Christianity includes suffering in the category of values: "Life is a huge workshop in which the souls of people become cleaner and prepare for a transition to a different, better world".

Christianity delimits just suffering and suffering for "good deeds", "suffering for the truth". It is suffering "for the truth" that brings man closer to God: "But if you suffer for the truth, you are blessed" [14]. Suffering is considered as something sent to a man by God, and if so, any suffering is inevitable and must be endured: "Bear suffering, therefore, as the good warrior of Jesus Christ" [14].

Besides, sufferings endured by a person teaches him to be condescending to other people. So sufferings improve a person. "It is unworthy to taste only good. Through sufferings the soul improves" - this quotation of one of the firm's character clearly conveys Christian attitude to the idea of suffering. It is true that believers view sufferings as a way to improve, an opportunity to approach God, that is, sufferings in Christian conception is perceived as God's mercy, his benevolence to a man, designation of a man as one of the chosen ones. That is why suffering itself can be regarded as a Christian value.

Unlike Christianity, where suffering is elevated to a cult and is an integral part of human life, "guarantee" of salvation and a happy existence in another world, the philosophy of Buddhism focuses on the idea to make a person free from suffering.

Like any other religion, Buddhism promises that people can get rid of sufferings, passions, fear of death, etc. However, denying the immortality of soul, Buddhism sees no sense to pursue eternal life (in heavens) since eternal life from the point of view of Buddhism is only endless series of reincarnations, a change of bodily shells. Unlike other religions, Buddhism does not recognize providence and emphasizes that the fate of a person depends only on his own efforts: "Canal builders let water, archers obey an arrow, carpenters subjugate a tree, sages humble themselves".

The most important concept for Buddhists is the concept of dharma (law, truth, path), it represents the teachings of Buddha, the highest truth that he revealed to all beings. Dharma literally means "support", "something that supports". In Buddhism the word "dharma" means moral virtue, primarily moral and 
spiritual qualities of Buddha, which all believers must imitate.

The doctrine of Buddhism rests on four noble truths: about suffering; about the cause of any suffering; about eliminating the cause of suffering and about the way to end suffering: "The good truth is that there is suffering. Birth - is suffering, old age - is suffering, illness - is suffering, death - is suffering; connection with what is unpleasant is suffering; leaving what is pleasant - is suffering; lack of possibility to achieve the desired - is also suffering".

The main goal of Buddhism is to achieve enlightenment or nirvana - a special state of consciousness in which understanding of the true meaning of things is achieved and occurs deliverance from passions and ignorance that tie everyone to sansara - an endless chain of earthly incarnations.

Buddhism knows the 8 -stages way (path), the way to get rid of sufferings of present life: "This 8 -stages way (path) is: the right views, the right intentions, the right speech, the right actions, the right lifestyle, the right efforts, the right awareness and the right concentration". Such 8-stages way (path) contains three main groups of exercises: exercises in morality, contemplation and wisdom: culture of behavior (correct thoughts, correct words and actions), culture of meditation (correct awareness and concentration) and culture of wisdom (correct views - knowledge of noble truths). Buddhism does not only testify to the possibility of liberation from suffering, but also states the way in which each person is able to achieve freedom and even become a Buddhist (enlightened). All these points differ from other wellknown religions - not any other religious doctrine recognizes that a person can make himself a God-like creature by his efforts, having achieved the highest goal to stop sufferings, to achieve liberation from all that belongs to the earth (nirvana).

Islam, to certain extent, interprets sufferings of this life as trials sent to a person; and in this it echoes Christianity: "We will certainly test you with insignificant fear, hunger, loss of property, people and fruits. But please the patient ones who, when they are in distress, say: "Truly, we belong to Allah, and we will return to him"; "They receive blessing of their Lord and his mercy. They follow a direct path" (Quran, 1999). Suffering is a kind of test that a person must endure to enter paradise in the future: "Or did you believe that you would enter Paradise without experiencing what befell your predecessors? They were afflicted by poverty and disease. They experienced such upheavals that the Messenger and those who also believed said to him: "When will the help of Allah come?" Truly, Allah's help is close" [15].

Trials and sufferings are given to everyone. Islam emphasizes that even the prophet Muhammad was given difficulties and trials: "Most of all people are tested by the prophet, then those who were closer to them (by their faith), then those who were closer to these. And a person is tested according to the degree of his religion (faith). If he was steadfast in religion, then his trials also increased. If there was weakness in his faith, then he was tested according to the degree of his religion. And the slave will suffer deprivation and distress until they make him walk on the earth free of his sins". In our opinion, this position of Islam, to some extent, echoes the Christian message - "To whom much has been given, from that one much will be asked", recorded in the paremiological fund of the Russian language. Along with suffering, Islam pays special attention to patience, which is considered as grace and blessing of the Most High, which is given to people and allows them to overcome all difficulties of the life.

\section{Conclusion}

Thus, sufferings occur in person's life in order to teach him to follow moral laws established by the Almighty. Sufferings and misfortunes are a test to a person's faith and morality. Islam teaches that whenever a person faces some misfortune, he must ask himself: "Didn't he violate any law of Allah?". And if it is seen as a kind of punishment, a person must ask for forgiveness and try to change his life; if it is a kind of test a person should make some efforts and pass this test.

We should notice that since human existence cannot be completely devoid of difficulties, troubles, experiences that inevitably entail the emergence of negative emotions, none of the world religions can circumvent the comprehension of such a phenomenon as suffering. Each religion offers slightly different ways to overcome suffering (for example, Christianity and Islam, on the one hand, and Buddhism, on the other), however, all world religions agree on one thing - it pays maximum attention to the phenomenon of human suffering and states the necessity to help a person if not to get free of the sufferings completely (which is impossible) at least to make the existing state of sufferings easier.

\section{References}

1. E.V. Bobyreva, O.A Dmitrieva, M.R Zheltukhina. \& M.V. Busygina, Advances in Social Science Education and Humanities Research, 97, 52-56 (2017).

2. E.V. Bobyreva, Religious discourse: values, genres, linguistic characteristics (based on Orthodox creed) (Volgograd: Peremena, 2007).

3. E.A. Kozhemyakin, Discourse approach to the study of institutional culture (Belgorod: Publishing House of BelSU, 2008)

4. A.A. Ivin Axiology: book for academic undergraduate studies ( M.: Yurait, 2018)

5. E.V. Bobyreva, M.R. Zheltukhina, K.G. Korovina, \& M.V. Busygina, SHS Web Conf, 69, 00021 (2019).

6. B. Malinovskiy, Selected: Dynamics of culture (M.: ROSSPEN, 2004).

7. N.D. Arutyunova, Language and the world of a man (M.: Languages of Russian culture, 1999).

8. I.E. Sedankina, Axiology of religion (Kazan: Publishing House of Kazan University, 2013). 
9. I. Kant, Study of clarity of the principles of natural theology and morality (M.: Nauka, 1985)

10. Yu.S. Garanov, Christian values in modern domestic cinema industry: philosophical analysis: autoref. diss. .... cand. philol, sciences (Astrakhan, 2014).

11. S.I Ozhegov, Interpretive Dictionary of the Russian Language (M.: Azbukovnik, 2000)

12. Yu.V. Gritskov, Phenomenon of suffering and the ways of its development in culture.... diss... doctor of philol.. sciences (Omsk, 2006)

13. E.V. Bobyreva, Linguistic and cultural characteristics of religion as the basis for the formation of values" guidelines of society: monograph (Saint Louis, Missouri, USA: Science and Innovation Center Publishing House, 2019)

14. Bible Books of the Holy Scriptures of the Old and New Testaments (Brussels, 1973)

15. Quran. Translation of meanings and comments by V. Prokhorova (Moscow-Damascus: Al-Furkan, 1999). 